\title{
Peace Was Made Here: The Tercentennial of the Treaty of Utrecht, 2013-2015
}

\author{
Renger E. de Bruin
}

Performances of Peace, the topic of this volume, has been dealt with in the previous chapters with regard to the period of the Treaty of Utrecht itself. In this contribution, I will deal with the way this peace was commemorated 300 years later. The tercentennial, of which the conference 'Performances of Peace' was also a part, gave rise to debates both on its historical meaning and the political message for today. The tension between past and present in the celebration will be a major element of this article. A comparison with the jubilee of the other major peace treaty in early modern history, Westphalia, is easily made. ${ }^{1}$ In the previous chapter, Jane O. Newman deals with the tercentennial of the Peace of Westphalia in both France and Germany in the immediate post-war context. ${ }^{2}$ In 1998, half a century later, 35 o years of Westphalia was commemorated in the two peace cities of Münster and Osnabrück, as well as in the Netherlands. For the celebration of the Treaty of Utrecht, Westphalia 1998 served as a source of inspiration, but was not followed as an example. A major difference was the relative obscurity of 1713 among a wider audience, whereas 1648 had been widely known for a long time. The challenge of commemorating an unknown event is one of the topics in this article. I participated in both the Westphalia and Utrecht commemorations, so, in a way, it will a personal account of the commemoration projects. The international exhibition 'Peace Was Made Here' is the central element. This exhibition was organized by museums in four cities that hosted negotiations leading to treaties in the framework of the Treaty of Utrecht: Utrecht, Madrid, Rastatt and Baden. Like Westphalia 1998, the peace cities of the past were the commemoration venues of today. I will analyse the concept of this exhibition (based on academic research), its organization and its tercentennial context.

1 Renger E. de Bruin and Alexander Jordan, 'Commemorations compared: Münster-Osnabrück (1998) and Utrecht-Rastatt-Baden (2013-2014), in Pax perpetua. Neuere Forschungen zum Frieden in der Frühen Neuzeit, ed. Inken Schmidt-Voges, Siegrid Westphal, Volker Arnke \& Tobias Bartke (München: R. Oldenbourg Verlag, 2010) 81-100.

2 See chapter 14 in this volume.

(C) KONINKLIJKE BRILL NV, LEIDEN, 2015 | DOI 10.1163/9789004304789_017 


\section{Commemorating an Unknown Peace}

During the celebrations in 2013 it was impossible to escape the peace of 300 years ago in Utrecht and its surroundings. By the autumn of 2013 most inhabitants and visitors of the city must have noticed the flags, posters, adds, TV programs or the large picture by the British photographer Red Saunders on the town hall, even if they had not participated in one of the numerous activities organized by the commemoration committee, the 'Stichting Vrede van Utrecht' (Foundation Peace of Utrecht). ${ }^{3}$ A decade earlier, the Peace of Utrecht was a historical event unknown in the Netherlands and even in Utrecht itself. The few people who had a clue often mixed it up with the Union of Utrecht of 1579. This ignorance of such an important event in the country where it took place, contrasted to the situation in Britain, where the Treaty of Utrecht had long been part of the well-known core of historical knowledge. In an episode of Monty Python's Flying Circus, two miners in Wales get into an argument about whether the Treaty of Utrecht was concluded in 1713 or in 1714, causing a dangerous situation a mile underground. John Cleese and his companions must have taken it for granted that the Treaty of Utrecht was widely known among their audience in order for them to make a point with their sketch.

The reason for this difference in appreciation is quite obvious. For the Dutch the Union of Utrecht as the founding of their nation and the Peace of Münster as the international recognition of their independence were far more glorious than the Treaty of Utrecht. The negotiations in Utrecht were rather humiliating for the Dutch envoys and the final results disappointing. The phrase from the French ambassador Melchior de Polignac: 'nous traiterons chez vous, de vous et sans vous' expressed the superiority of the great powers and fed the fear of an Anglo-French deal excluding the smaller allies. ${ }^{4}$ In the Dutch collective memory this phrase was symbolic for all the negative connotations with 1713 . The Treaty of Utrecht marked the end of the Golden Age and the role of the Dutch Republic as a great power. For in the nationalist view of the nineteenth

3 For an overview of the activities of the Tercentennial Foundation, both the preparations and the celebration in 2013, see: 9 jaar Stichting Vrede van Utrecht 2005-2013, ed. Lieke Hoitink and Petra Orthel (Utrecht: Stichting Vrede van Utrecht, 2013).

4 Cited by J.W. Gerard, The Peace of Utrecht (New York - London, 1885) 275-276; David Onnekink, 'The Treaty of Utrecht 1713,' in In Vredesnaam. De Vrede van Utrecht, Rastatt en Baden, 1713-1714/ Peace was made here. The Treaties of Utrecht, Rastatt and Baden, 1713-1714/ Friedensstädte. Die Verträge von Utrecht, Rastatt und Baden, 1713-1714, ed. Renger de Bruin and Maarten Brinkman (Michael Imhoff Verlag, Petersberg, 2013), 65. Exhibition catalogue for Centraal Museum Utrecht, Wehrgeschichtliches Museum Rastatt, Historisches Museum Baden). Alexander Jordan was co-editor of the German edition. 
century this peace should be forgotten rather than remembered like glorious periods such as the Eighty Years' War. For the British, on the other hand, the Treaty of Utrecht was an enormous success, creating a balance of power in Europe and a British dominance at sea with an extension of overseas' possessions, notably in Canada. On the European continent, 1713 was overshadowed by the liberation from the French dominance exactly a century later.

So when the governments of the city and of the province of Utrecht decided to celebrate the tercentennial of the Treaty of Utrecht, it was quite a challenge to commemorate a forgotten event. The task was much more complicated than it had been in 1948 and 1998 for the Peace of Münster, in 1979 for the Union of Utrecht or in 1995, half a century after the liberation from the Nazis. Originally the tercentennial served as a historical occasion for the application to become European Cultural Capital in 2013. Due to the extension of the European Union the Netherlands' next turn was five years later, but the decision was to be made in 2013. The 'Stichting Vrede van Utrecht' was commissioned to organize the commemoration and to bid for European Cultural Capital. The preparations by the Foundation for the tercentennial focused on the current political message of the Treaty of Utrecht rather than holding a primarily historical commemoration such as 350 years Westphalia in 1998. In that sense, the 2013 tercentennial resembled that of Westphalia of 1948 described by Jane Newman: resurrected France and Germany looking for peace as a political message three years after the Second World War. ${ }^{5}$ Although European integration was an underlying thought in the 1998 commemoration, this was not as obvious in the festivities as it was in 1948 or 2013 .

In this way the 3ooth anniversary of the Treaty of Utrecht was meant as an overture for the nomination as European Cultural Capital. All the activities, from festivals and concerts to exhibitions and conferences, should serve to convince the European jury to opt for Utrecht. The presentation of the bid book in October 2012 clearly incorporated the perspective of the tercentennial of the Treaty of Utrecht and the organization of the Cultural Capital. Great was the disappointment, a month later, when Utrecht did not survive the first round. In the end, the northern city of Leeuwarden won the nomination and will serve as European Cultural Capital in 2018, together with Malta. Although the 'Stichting Vrede van Utrecht' had to give up on its final goal, it went on to make the tercentennial of the Treaty of Utrecht a success. On 21 September 2013 the tercentennial finished off with a final manifestation, 'Sound of Freedom,' on the former NATO airbase Soesterberg. The evening with singers, speakers

5 See chapter 14 in this volume. 
and a weapons demonstration, ended like the start of the show on 13 April (The Battle for Peace), with fireworks resembling the fireworks of $1713 .{ }^{6}$

\section{The Treaty of Utrecht as a Beacon of Peace for the Twenty-First Century}

The commemoration committee emphasised the perspective of peace, tolerance and European integration. This program served as a counterbalance to populist tendencies in Dutch society during the preceding decade. In the second half of the twentieth century the Netherlands was considered as a haven of tolerance and liberty, but after the turn of the century ethnic tensions came to the surface. In the wake of $9 / 11$ a right-wing populist movement entered the political stage. Its leader, Pim Fortuyn, was killed in May 2002 by a left-wing activist. In November 2004 the controversial film director Theo van Gogh was assassinated by a Muslim fundamentalist. The rise of a new populist movement led by Geert Wilders made him — an advocate of struggle against the political Islam and for restrictions on immigration - the best known Dutch politician abroad. His opponents desperately searched for arguments to counter his one-liners that brought him great success in the 2006 and 2010 general elections. History might offer such arguments: the tolerance of the seventeenth century protecting freethinkers such as René Descartes or Baruch de Spinoza, the waves of immigrants finding a new home in the Netherlands or the long tradition of 'polder democracy,' the politics of consensus dating back to Middle Ages. The Treaty of Utrecht might offer a new inspiration.

Current concerns were central in the events during the long preparation period as well as in the activities during the commemoration between April and September 2013. Central was a document, 'the Utrecht Principles,' signed by the then Crown Prince Willem Alexander in 2008. These principles, claimed to be derived from the 1713 Treaty of Utrecht, implied: respect for cultural, ethnic and religious diversity; the power of art and multilingualism for social sustainability and, finally, exchange of knowledge of social cohesion and innovation. ${ }^{7}$ It is not surprising that the authors of the Utrecht Principles did not quote articles from the 1713 treaty documents to underline the historical origin of these principles. With a more general approach to peace between countries

6 9jaar Stichting Vrede van Utrecht, 96-101; 231. For a comparison between the fireworks of 1713 and those of 2013, see chapter 13 in this volume.

7 'The Utrecht Principles,' Stichting Vrede van Utrecht, http://www.vredevanutrecht2013.nl/ over/the-utrecht-principles, accessed 29 March 2015. 
and European cooperation, a message for today could have been derived from the preambles of the various 1713 treaties and the writings of the Abbé St. Pierre, who pleaded for a European security system. The opening sentence of the preamble of the British-French treaty of 11 April 1713 could have served as point of departure for a modern peace statement: 'WHEREAS it has pleased Almighty God, for the glory of his name, and for the universal welfare, to direct the minds of Kings for the healing, now in his own time, the miseries of the wasted world, that they are disposed towards one another with a mutual desire of making peace. ${ }^{8}$ However, the condemnation of racism was difficult to find in the original texts. As for the condemnation of slavery and slave trade, the treaty itself was quite to the contrary, since it gave the asiento de negros, the monopoly on the transatlantic trade in Africans on the Spanish colonies, to the British for 30 years. Nevertheless, a conference on the topic of slavery was organized on 21-22 June 2013. Other activities in Utrecht related to diversity were the festival Cross Culture (13-14 July 2013) and the project "The Peaceful City" ("De Vreedzame Stad"). ${ }^{9}$ This project, initiated by the local police, set examples of conflict control and co-operation, particularly in immigration neighbourhoods with high crime rates.

In Rastatt the title of the commemoration had a European peace message: 'Frieden für Europa-300 Jahre Rastatter Frieden 1714-2014'. However, the Rastatt version of 'Peace Was Made Here' at the Wehrgeschichtliches Museum and a staging of the events of 1714 at Rastatt Palace by museum director Alexander Jordan and castle curator Petra Pechacek had a historical undertone. The same was true for the exhibition at the Town Museum. ${ }^{10} \mathrm{~A}$ day devoted to German-French relations was organised in the light of friendship with the neighbouring Alsace. The texts of leaflets and programs were also in French. In Baden the message of peace for today was stronger than in Rastatt. The local government wanted to use the tercentennial for the promotion of the town both as a spa and a conference centre. During the official celebration ('Festakt') on 6 September 2014, the issues of mutual understanding and

The Treaty of Peace and Friendship between the most Serene and most Potent Princess Anne, by the grace of God, Queen of Great Britain, France, and Ireland, and the most Serene and most Potent Prince Lewis, the XIVth, the most Christian King, concluded at Utrecht, the 11. Day of April 1713. Wikisource, http://en.wikisource.org/wiki/Peace_and_Friendship_ Treaty_of_Utrecht_between_France_and_Great_Britain; accessed 2 April 2015.

99 jaar Stichting Vrede van Utrecht, 140-147, 180-181.

10 See: Alexander Jordan and Petra Pechacek, 'Frieden für Europa-30o Janhre Rastatter Frieden, 1714-2014, ein Rückblick, Der Bote aus dem Wehrgeschichtlichen Museum 46 (2014): 4-11. 
European cooperation were underlined. Surprisingly enough, the Swiss town of Baden contained the strongest European element of the four cities, and EU bunting carried first in the parade of flags. National, regional and local politicians repeated the necessity of peace and European cooperation in their speeches. The city slogan 'Baden ist' was in this case 'Baden ist.... Frieden verhandeln' (Baden is negotiating peace). ${ }^{11}$ Near the railway station there arose an art project designed by a local sculptor: a peace bridge constructed with panels containing messages. On the closing day of the project, 25 January 2015, the last panel, signed by the curators of the exhibition, was fit in.

The political support was evident in all four venues. Politicians from local, regional and even national levels attended the openings of the commemorations. In Utrecht the commemoration started with minting a special 10 euro coin by the Dutch Secretary of State for Finance in the city hall, followed by an opening act in the Centraal Museum: the unveiling of the showcase with the Franco-Dutch peace treaty of 11 April 1713 by the French ambassador in the Netherlands Pierre Ménat and the Dutch Minister of Foreign Affairs Frans Timmermans. In the evening, a concert in Utrecht Cathedral with Handel's Utrecht Te Deum was hosted by Queen Beatrix. It was to be one of her last public appearances before her abdication. The mayor of Utrecht and the head of the provincial government were present at all the opening events, as were foreign ambassadors and delegations from Rastatt and Baden. In Madrid the exhibition was opened by the ministers of Foreign Affairs and Defence. In Rastatt the mayor, the prime minister of the state of Baden-Württemberg and Prince Bernhard of Baden (descendant of the last grand duke) hosted the opening. In Switzerland all political levels addressed the audience at the official commemoration of the Treaty of Baden on 6 September 2014 with their pro-European messages.

\section{A European Exhibition as the Historical Anchor of the Commemorations}

Whereas the Utrecht and the Baden commemorations had a strong contemporary, political character, the exhibitions in the Centraal Museum Utrecht and the Historisches Museum Baden emphasized historical elements. In their educational programs a link to the present was clearly made, but the presentation of the objects was historical. A slide show with images of war and peace

11 For a project description of the Swiss venue see: Stafanie Brunschwiler and Carol Nater Cartier, Frieden verhandeln (Baden: Historisches Museum Baden, 2014). 
from the War of the Austrian Succession to the Syrian Civil War connected past and present. At the venues in Madrid and Rastatt the commemorations were not embedded in a contemporary context, although Rastatt presented the slide show and, like Utrecht and Baden, offered visitors the possibility to leave a personal peace message. The European exhibition project had as a common title in English: 'Peace Was Made Here. The Treaties of Utrecht, Madrid, Rastatt and Baden'. Each partner was free to choose a name in the vernacular: 'In Vredesnaam', 'En Nombre de la Paz', 'Frieden für Europa' and 'Frieden verhandeln'.

All four venues had a chronological story line. In Utrecht and Rastatt European history was shown from the Reformation onwards, placing the Treaty of Utrecht into the perspective of the Wars of Religion and modifying the opinion that Westphalia was the end of this period. Both exhibitions started the show with a portrait of Martin Luther and ended with announcements of the peace in 1713/14 and an allegorical painting on the treaties of Utrecht and Rastatt. The difference between the two venues was the geographical focus (the Low Countries vs the Upper Rhine region) and the selection of objects, but the structure of the two was basically the same. Madrid showed a shorter time span (starting around 166o) and a geographical focus on Southern Europe, although the North Sea coasts and Rhine/Danube basin were not neglected. A painting of the Battle of Oudenaarde in Flanders even served as the logo of the Spanish exhibition. ${ }^{12}$ The Madrid venue focused on the war in Spain but placed it in the perspective of the pan-European conflict, adjusting the common view in Spain to see the War of the Spanish Succession primarily as a civil war. Their colleagues in Baden opted for more or less the same period, but paid much more attention to the aspect of the Swiss mercenaries that served both sides during the war. The new director of the Historisches Museum, Carol Nater Cartier, who took over from Barbara Welter in the spring of 2013, added a gender element, the role of women in the creation of policy at the courts. Although the Swiss venue did not start with the Reformation, the emphasis on religious conflict was as strong as in Utrecht and Rastatt. Iconic was a statue of Louis XIV trampling Heresy, a loan from the Palace of Versailles. ${ }^{13}$

The historical content of the selection was that of authentic artefacts. In all venues documents, paintings, sculptures, prints, medals etc. from the time

12 The Battle of Oudenaarde by Joseph van Bredel, oil on canvas (1716), MOU City Hall, Oudenaarde, inv. nr. o1261, see: In Vredesnaam, ed. De Bruin \& Brinkman, 144.

13 Louis XIv trampling Heresy, marble statue by Thomas Gobert, Musée National des Châteaux de Versailles et de Trianon, inv. nr. mv 8679. See De Bruin and Brinkman (ed.), 116 . 
itself told the story. Central were original treaty documents with seals and signatures from the national archives of Austria, Spain and the Netherlands. In the Utrecht venue we showed the original Dutch-French treaty of 11 April 1713. To emphasise the point that the Peace of Utrecht was not a single treaty we displayed this document together with printed versions of other bilateral treaties concluded in Utrecht, as well as printed editions of the treaties of Baden and Rastatt. We also showed a (contemporary) Dutch translation of the French text.

It was a long search for authentic objects; working through catalogues, books, articles, on-line databases, old-fashioned card-index boxes, and endless talks with colleagues at home and abroad. The aim was to find authentic artefacts to tell the story of war and peace. Most obvious were the abovementioned key documents, as well as portraits of protagonists (such as Louis XIV, Queen Anne, Prince Eugene of Savoy and the main negotiators in Utrecht). Pictures of events during the long period covered by the storyline of the exhibitions, from the tyranny of Alba to fireworks celebrating the peace of 1713 were welcome finds in the search. A challenge was to find a painting of the negotiations or the signing, similar to those of Münster and Nijmegen. For Utrecht, however, we only found engravings. A request for a loan of a painted group portrait of negotiators in Baden from the collection of the Château de Versailles was refused because of its fragility. In a private collection in Hamburg we found an allegory on the treaties of Utrecht and Rastatt. It was a modello for a large painting by the Napolitan artist Paolo di Matteis, of which only a fragment has survived. The painting shows a self-portrait of di Matteis working on the allegorical marriage of Habsburg and Flanders surrounded by traditional symbols of peace and references to the results of the treaties, e.g. the Vesuvius for the transfer of Naples to Austria. ${ }^{14}$ The painting was shown at all four venues. During the exhibition it was bought by the Centraal Museum Utrecht from the collector.

As in the 1948 and 1998 exhibitions on the Treaty of Westphalia, the number of objects representing war outnumbered those representing peace. For the 2013-2015 exhibition the most striking war-related element was a selection from a private collection of battlefield archaeology related to the Battle of Blenheim in 1704. The owner, a contractor in the Bavarian village of Blindheim (Blenheim), who permanently loans objects to Blenheim Palace and Schloss Höchstädt, generously offered a few hundred objects (bullets, weapons and even human remains) for the venues in Utrecht, Rastatt and Baden. For the visitors the Blenheim scenery, together with an animation of the battle, was one

14 Liesbeth M. Helmus, 'Allegories on Peace: Nijmegen, Ryswick and Utrecht-Rastatt,' in In Vredesnaam, ed. De Bruin \& Brinkman, 94-96. 
of the elements in the exhibition that most impressed them. The Blindheim collection was one of the elements shown in most or all venues. Some objects, for example the portraits of Prince Eugene of Savoy and Marshal Villars, who fought as commanders against each other, but who made peace in Rastatt and in Baden as envoys for their sovereigns, served to illustrate both warfare and the peace negotiations.

In Madrid the picture of a battle (Oudenaarde 1708) served as the icon of the exhibition on banners, posters, leaflets and the catalogue, while Utrecht used a fragment of the allegorical painting by Paolo di Matteis, Rastatt a photo of the Residential Palace and Baden an engraving made on the occasion of the negotiations in 1714 .

The artefacts representing war and peace came from eighty-six collections from eight different countries (Austria, Belgium, France, Germany, the Netherlands, Spain, Switzerland and the United Kingdom). It was a wide range of collections, including those from famous institutions like the British Museum, the Prado, the Château de Versailles, the Bibliothèque Nationale or the Alte Pinakotek. However, local museums and private collectors, such as the contractor in Blindheim, also offered their contributions to the exhibition. A small selection travelled along all four venues, a larger number was shown on two or three venues and some only by one of the participants. The differences in selection had to do with the focus, costs of transport, and the availability of objects. Works on paper or textiles, for example, can be shown only for a limited period for conservation reasons. Despite these differences the exhibitions on the four venues all told the story of the Treaty of Utrecht as the end of a large European conflict.

\section{Research as a Base for an Exhibition}

The team preparing the international historical exhibition strove vigorously for a content based on recent academic research. In that sense, the project resembled the commemoration of the Treaty of Westphalia in 1998. The Münster and Osnabrück shows in particular were rich in objects and information fed by the work of many scholars and counselled by a 'Wissenschaftlicher Beirat'.15 The research was published in a three volume catalogue. ${ }^{16}$ In the exhibition

\footnotetext{
15 De Bruin and Jordan, 82-86.

16 Klaus Bußmann \& Heinz Schilling (ed.), 1648, Krieg und Frieden in Europa/1648, War and Peace in Europe 3 vol. (Münster-Osnabrück: Veranstaltungsgesellschaft 350 Jahre Westfälischer Friede mbH, 1998).
} 
a large number of artefacts was shown, 1260 of which were described in the catalogue. It was all impressive, maybe overwhelming for the common visitor. For the 1713 commemoration we wanted to avoid this. It was our aim to make an exhibition that derived its content from recent research, but presented in an understandable and easy way. We wanted to filter the information, so to speak. Alexander Jordan, Bernardo García and I served as intermediaries between the specialists in the field and the exhibition teams. We attended conferences and spoke intensely with the participants. David Onnekink in particular was an important partner in this respect.

Most authors of the exhibition catalogue were recruited from the conferences on peace in early modern Europe held in Osnabrück, Madrid and Utrecht between 2008 and 2013. Maarten Brinkman and I edited the catalogue, which was published in Dutch, German and English, serving the Utrecht, Rastatt and Baden venues. ${ }^{17}$ This catalogue was much smaller than the MünsterOsnabrück one previously mentioned: only 190 pages, containing nine essays and 95 descriptions of artefacts, a selection of the objects shown at the venues. The separate catalogue (in Spanish only), issued by the Fundación Carlos de Amberes and edited by Bernardo García, also benefited from the conference series. This publication had the same outline: essays by specialists and descriptions of the artefacts, in this case all $78 .{ }^{18}$

The curators of the exhibition adapted the information further with their educational colleagues. It was their task to tell the story of the peace to specific target groups. This was a new stage in translating knowledge. While the curators had used the results of academic research to develop a comprehensible exhibition concept, this concept now had to be tailored to specific groups such as school children, elderly visitors etc. Also, the educational staff developed products like an audio guide or games for the general audience. They checked and adapted the texts and animations for the visitors, e.g. the target groups. A European Negotiation Game was developed especially for the exhibition. Guided by a game master, visitors could act like participants at the negotiation table. This table was a world map, which roughly represented the situation of 1712. The players had to fulfil their assignment with cards, dices and pawns. Families as well as staff members of the history department of the Rijksmuseum played this game with great enthusiasm. By doing so they processed the knowledge acquired during the exhibition visit. Their conversations

\footnotetext{
17 In Vredesnaam, ed. De Bruin \& Brinkman.

18 Bernardo García (ed.), En Nombre de la Paz. La Guerra de Sucsesión Españolay los Tratodos de Madrid, Utrecht, Rastatt y Baden 1713-1715 (Madrid: Fundación Carlos de Amberes, 2013).
} 
with the game masters also contributed to digest the impression the exhibition made, sometimes in quite an emotional way. The way artefacts were presented proved important for bringing across the message to the audience. An attractive design makes the message stronger, but it should not be too dominant. Curators need to find a balance between aesthetics and content. For 'Peace Was Made Here,' the Utrecht and Baden venues hired professionals from respectively Amsterdam and Zurich. Rastatt and Madrid made the presentation in-house, although Rastatt used elements of the Utrecht presentation, as did Baden. The designs were very much appreciated. The designers of the Utrecht venue, De Vrijer \& Van Dongen, were even awarded a silver medal by the European Design Awards in Cologne, on 24 May 2014. ${ }^{19}$

Despite the popularization of the topic, essential new conclusions from the research front were incorporated: the questioning of the Treaty of Westphalia as the end of religious warfare with a stronger emphasis on the confessional element in the politics of Louis XIV and his adversaries, the impact of war on society, the role of the financial sector and the culture of peace conferences in early modern Europe. To demonstrate these conclusions, the curators selected appealing objects such as the sculpture of Louis XIV trampling Heresy, skulls from the Blenheim battlefield and a money carriage used at the Amsterdam stock exchange from the Dutch Royal Collections. These artefacts stand for the continuity in religious warfare, the atrocities of war and the financing of warfare. The labels given to these objects, the descriptions in the catalogue, the related essays in the same catalogue, the audio guide, the children's program; all these elements served to translate the results of academic research to the various target groups. From questionnaires and reactions of visitors to the game master, guards and curators it was evident that visitors understood and appreciated the new insights. A relatively unknown episode in history had been brought to the attention of professional historians, policy makers and the general public.

During the conference of which this volume is the book of proceedings, the international experts could reflect on the exhibition. The final session took place in the Centraal Museum and after an introduction the participants visited the exhibition. Such an interaction also took place with students. David Onnekink and I gave a BA/thesis course on the War of the Spanish Succession and the Treaty of Utrecht at the History Department of Utrecht University for three years entitled 'World War o.1'. One of the tasks given to students was to develop an exhibition concept on a subject related to the theme of the course,

19 'De Vrijer van Dongen,' Centraal Museum, Utrecht. http://www.devrijervandongen.nl, accessed 26 April 2015. 
for example Queen Anne's War, the role of the Duke of Marlborough, the court of Philip V or religious propaganda. The participants of the third year (20132014) could visit the exhibition in the Centraal Museum a few weeks before its dismantling at the end of September 2013. The students could match their ideas about transferring academic knowledge to an exhibition with what they saw in the museum.

\section{The Exhibition as a European Cooperation Project}

From the start it was evident that the commemoration project had to be a European event. The initiative was taken by Utrecht, but foreign contacts were made at an early stage. In keeping with the cultural capital bid, connections with Brussels and the cultural capitals during the preparatory period were selfevident, but connections were also made with Malta, the EU Member State co-organizing the event in 2018. Utrecht had already developed common projects with Maltese counterparts from 2006 onwards. On the academic research front the international conference series and the contacts connected to these have just been mentioned.

For the curators of the historical exhibition a European dimension was intended from the start, not only in content, but also in organization, even in the choice of venues. Museums in Rastatt and Baden were contacted at an early stage since the treaties of Rastatt and Baden of 1714 are so closely connected to the Treaty of Utrecht in the realm of historiography. Both the Wehrgeschichtliches Museum Rastatt and the Historisches Museum Baden responded enthusiastically to the Utrecht request to join the project. The Rastatt Museum was later joined by Staatliche Schlösser und Gärten BadenWürttemberg (SSG). Talks with French and British museums eventually did not result in cooperation, but via the conference line the preparation group came into contact with the Fundación Carlos de Amberes in Madrid. The foundation has as its mission the fostering of cultural historical ties between Spain and the former Spanish Netherlands. According to its website 'the Foundation cooperates via all sorts of cultural, political and scientific initiatives with those countries-Belgium, The Netherlands, Luxembourg and northern France-in the adventure of building a common space: a united Europe. ${ }^{20}$ In view of this, an exhibition on the Treaty of Utrecht fitted in with the core of its mission. So, the Fundación entered the project in the Summer of 2011. Since one of the

20 'The Objectives of the Foundation,' Fondacion Carlos de Amberes. http://www.fcamberes .org/paginas/en/en_stc_pre.htm, accessed 12 April 2012. 
separate treaties constituting the complex that formed the Treaty of Utrecht was signed in Madrid, the concept for the exhibition cooperation was that the cities of peace in $1713^{-1715}$ were to be the venues of the commemorations three hundred years later.

Shortly after the Fundación joined the cooperation, we applied for a European grant. The program Culture 2007 of the European Commission offered the possibility of a substantial financial support for the exhibition. Unfortunately the Swiss partner could not be a beneficiary since Switzerland was excluded from the program, not being an EU Member State, associate or candidate Member State, nor being part of the European Economic Area. ${ }^{21}$ Nevertheless Baden remained a full partner in the project. For the application, this was all rather complicated. It had to be stated that the Swiss partner would not benefit from the grant, but on the other hand we made clear that Baden was the final stage of the exhibition tour. This was solved by planning the Baden commemoration after the end of the grant period. This period was set for July 2012 till June 2014 and the signing of the Treaty of Baden was 7 September 1714 making the opening of the tercentennial exhibition 7 September 2014.

Essential to the application was the meaning of the Treaty of Utrecht for European history as a crucial moment in the development between a continent torn apart by religious conflict and the pursuit of hegemony, to a system of balance between great powers. Three hundred years later the cities hosting negotiations in 1712-1715 were the venues of the commemoration exhibition. In the application the link between past and present was made clear with a historical role for the exhibitions and catalogues and the transfer to the present through educational programs. The application was awarded with 87 points out of 100 (with a threshold for granting at 76 points). The grant was 200,000 euros on a total budget of 1.2 million (including salaries and overhead costs). The EU funded part of the project started in July 2012 and ended two years later. During the period the realization of three exhibition venues (Utrecht, Madrid and Rastatt) took place as well as two conferences (Madrid and Utrecht). ${ }^{22}$

Writing the application and the final report was complicated and time consuming. Complicated forms had to be filled out in order to meet the financial and legal rules of the EU. In the final report emphasis was placed on the

21 In the new program Culture 2014-2020 the rules have been changed; Switzerland is now included.

22 For the proceedings of Madrid conference (2012) see: Vísperas de Succesión. Europa y la Monarquía de Carlos II, ed. Bernardo J. García García and A. Álvarez-Ossorio Alvariño (Madrid: Fundación Carlos de Amberes, 2015). This volume is the book of proceedings for the Utrecht conference of April 2013. 
financial figures, showing that the project management was sound. However, we also demonstrated, through the number of visitors, reactions and press reviews, that we had succeeded in bringing across the meaning of the Peace of Utrecht as a milestone in European history. This indeed has been the accomplishment of the commemoration project: to have placed Utrecht in line with the great peace treaties, between Westphalia and Vienna. In the report we emphasized the importance of new academic research translated to a general audience of museum visitors, readers and event participants.

Apart from the international connection, the exhibition project also had a local embedding. The shows in the Centraal Museum Utrecht and in the Wehrgeschichtliches Museum Rastatt were related to other museums in town. In Utrecht this happened under the umbrella of the 'Stichting Vrede van Utrecht'. The Utrecht Archive showed the impact of the negotiations on local society, the National Museum on Religious Art and History Catharijneconvent worked with the topic of tolerance in early modern history, the Dutch Railway Museum displayed the role of trains in warfare and the University Museum showed the dilemmas of justice and reconciliation after conflicts (Yugoslavia, Uganda). ${ }^{23}$ The Rastatt exhibition was related to a common presentation at the local museum and the local archive on war and peace in the Upper Rhine Region.

\section{Reactions from Press and Visitors}

In the application to the EU the importance of good communication and a sound promotional plan was emphasized. It was stated that the exhibition as well as the education and participation program could be considered as communication tools: to communicate the abomination of war, the importance of the Treaties, and of dialogue and diplomacy in general for a peaceful and tolerant Europe. The 'Peace Was Made Here' project provided a unique opportunity to have older and younger target groups interacting: it combined a topic which had the natural attention of the elderly, with the use of digital media which appealed to the younger target groups. In the 'Studio,' interaction was stimulated and elderly became more familiar with digital media. An international symposium discussing the experiences with participation based on the 'Studio' concept, was held in Utrecht on 23 September 2014. The symposium was organized by the Centraal Museum and presided over by director Edwin Jacobs.

23 9jaar Stichting Vrede van Utrecht, 70-79. 
The 'Peace Was Made Here' project and its message were disseminated by press releases, press conferences, interviews, presentations, flyers, posters, advertisements on radio, TV, magazines and newspapers etc. In these messages the topicality of a historical subject and the thrill of authentic objects were emphasized. The media picked up on it eagerly. None of the four venues could complain of a lack of media attention. Local, national and international journalists came to the exhibitions and interviewed the curators. The national eight o'clock news in the Netherlands and Germany filmed in the exhibitions and interviewed the curators. There was even a film crew from Canada at the Utrecht venue. The result was broadcast from 25 August 2014. ${ }^{24}$ The attention of the media was also wide in Spain. Already at an early stage the foreign media were informed, through an international press conference in Utrecht in September 2012. The articles in the press and other media were mostly very positive.

In Utrecht, Rastatt and Baden the exhibitions could benefit from the communication and promotion activities for the tercentennial in the three cities. The 'Stichting Vrede van Utrecht' and the cities of Rastatt and Baden promoted the commemoration for months, from April to September 2013, from March to July 2014 and from September 2015 to January 2015 respectively. The three museums closely cooperated with the local tourist offices and other museums in town. The closest link was that between the Wehrgeschchtliches Museum and the Staatliche Schlösser und Gärten Baden-Württemberg (SSG). The Castle Foundation was in charge of the communication for both the exhibition 'Frieden in Europa' and the scenery in the Palace.

Crucial events were the openings of the exhibitions. The first was on 11 April 2013 in Utrecht with the already mentioned ceremony attended by Dutch Foreign Minister Timmermans and the French Ambassador Ménat, as well as a commemorative concert in Utrecht Cathedral in the presence of Queen Beatrix of the Netherlands (three weeks before her abdication). The opening of the Madrid venue with the ministers of Foreign Affairs and Defence and a row of European ambassadors attracted wide press attention. The third inauguration took place in Rastatt on 6 March 2014 with the prime minister of Baden-Württemberg and Prince Bernhard of Baden, member of the grand ducal dynasty that built the Palace of Rastatt. This event also drew wide media attention. Local, regional and national media paid attention to 'Frieden für Europa'. From the opposite banks of the Rhine Les Dernières Nouvelles d'Alsace paid attention to the tercentennial in Rastatt. Furthermore, the local newspapers in Rastatt wrote about the exhibitions in Utrecht and Madrid. 
The communication resulted in rising visitor numbers. In Utrecht more than 53,000 people visited the exhibition, in Rastatt WGM welcomed 15,000, SSG also 15,000 for the peace location in the Palace and 10,000 people attended the 'Schlosserlebnistag. The exhibition in the city museum drew 4,00o visitors. A few hundred of visitors attended the lecture program. The exhibition in Madrid attracted almost 8,00o visitors while the museum in Baden counted over 5,000. The Madrid and Baden numbers seem to be disappointing, but these two partners are small institutions. For the Historisches Museum 'Baden ist Frieden verhandeln' even resulted in an all-time high record of visitors.

\section{Conclusion}

Maybe I was a bit ironical about the peace message in the tercentennial of the Treaty of Utrecht. Some elements, such as the claim of the 'Utrecht Principles' to be derived from the treaty, were indeed rather far-fetched. However, a commemoration of an event hitherto unknown outside the circle of professional historians would never have been possible without the broad support that was generated by the political interest in the subject. 1713 was simply not as wellknown as 1648 to justify an elaborate and costly historical commemoration. Local, regional and national authorities facilitated the preparations and the realization of the project and the EU- grant even lifted it to an international level. This support gave us the time to prepare an exhibition that translated the results of recent research to a wider audience. The link with the academic research front was a series of conferences, one of which was 'Performances of Peace.' Curators of the exhibition participated and transferred the knowledge to concepts and contents of the museum shows. The story was told with authentic objects from dozens of collections in eight European countries. Closest to the realm of research were the catalogues with descriptions of objects and essays by participants of the conferences. The exhibitions with texts, labels and animations made the information highly accessible to the visitors and the confrontation with the authentic objects gave them the thrill of experiencing the past. The skulls and bullets from the battlefield of Blenheim and the seals and signatures on the treaty documents made the early Eighteenth century visible. Reactions from the visitors and reviews in the media confirmed our opinion that we had conveyed the story to the public. This worked in The Netherlands, Spain, Germany and Switzerland. The tercentennial of the Treaty of Utrecht was thus a successful performance of peace at four different national stages. 